\title{
A Tale of Two Tournaments: The Red Cross Games and the Early NCAA-NIT Relationship
}

\author{
Chad Carlson \\ Eastern Illinois University
}

\begin{abstract}
The purpose of this article is to explore the relationship between the National Invitational Tournament (NIT) and National Collegiate Athletic Association (NCAA). To do so, the author explores the Red Cross War Benefit Games, which pitted the champions of the two tournaments against one another, with the proceeds benefiting the Red Cross. These contests represented the only times the two tournaments or their teams interacted. The author explores the Games' significance and the manner in which they helped propel the NCAA men's basketball tournament to preeminent status.
\end{abstract}

Keywords: basketball, NIT, charity, championship, New York City

In 2005, the New York-based National Invitation college basketball tournament (NIT) charged the National Collegiate Athletic Association (NCAA) with violating antitrust laws. Following legal arbitration, the NCAA settled with the NIT, purchased its rights, and effectively placed it in the hands of an organization with whom it had been competing for decades (Litsky, 2005). This settlement marked the final step in the slow relegation of the NIT championship to second-class status behind the NCAA tournament.

This settlement also marked the end of a complex relationship between NIT and NCAA tournament organizers that began with the inception of the championships in the late 1930s. One central and well-known event sits at the nexus of this relationship. In 1951, college basketball found itself in the thick of a widespread gambling and point-shaving scandal involving players and teams hosted at New York's Madison Square Garden - the home venue for the NIT and a frequent host for NCAA championship games. As a result, public trust in the purity of college basketball waned. Subsequently, the NCAA distanced itself from Madison Square Garden and the New York-based NIT (see Fitzpatrick, 2000 and Rosen, 1978 for more information on the 1951 scandals).

Yet little has been written about the relationship between the NCAA and NIT leading up to this well-known event. What was the nature of the relationship from the onset of the NIT in 1938 and the inaugural NCAA tournament in 1939? Before the

Carlson is with the Kinesiology and Sports Studies Dept., Eastern Illinois University, Charleston, IL. 
scandal, many believed that the NIT was the premier event and the NCAA championship held a lower status. Nevertheless, that belief may not have been completely accurate since the NCAA and NIT championships both established reputations of providing high caliber basketball as they shared New York City's "Garden" and the prestigious fan base in the media capital of the world during much of the 1940s.

Within this decade college basketball tournaments, like many other social and cultural establishments in America, rallied during the war years with an unparalleled collective vision whereby many of those in power relegated petty personal issues for the greater good of the country and its citizens. In New York City, the NIT and NCAA cooperated with Madison Square Garden to host Red Cross War Fund charity basketball games. These "mythical national championship games" (Effrat, 1943) pitted the victors of the two tournaments at season's end from 1943 to 1945 with proceeds going to the Red Cross' War Fund ("Game Nets," 1943). These three Red Cross games represent the only times in which the two tournaments intermingled, and they seemingly only did so to aid the Red Cross war efforts.

After the war college basketball tournament organizers proved unable to rekindle the cooperative attitude that pervaded American society during the war. These postwar years saw both the NCAA and NIT championships grow in participation, prestige, and profits. Although both tournaments shared Madison Square Garden and enjoyed similar progress, the NCAA and NIT grew independently. Yet their similarities forced comparisons and economic competition within the scarce but growing college basketball market. Once the 1951 scandal forced both tournaments to reevaluate their methods of operation, the NCAA and NIT became increasingly unwilling to cooperate with each other, and the relationship deteriorated.

A closer inspection of the Red Cross charity games and their context provides a deeper insight into the foundation of these organizations' coexistence before the 1951 gambling scandal gave each tournament a proverbial black eye. This complicated relationship between them reveals the hurdles that early NCAA basketball tournament organizers faced and the decisions they made that helped their tournament eventually become the undisputed college basketball championship.

\section{The Creation of National Tournaments}

The growth and popularity of college basketball tournaments in the 1940s was preceded by shrewd public relations work a decade earlier. In 1933, Ned Irish, a metropolitan college basketball beat writer and future director of basketball at Madison Square Garden, arrived at Manhattan College to cover a local hoops showdown only to find the small gymnasium sold out. After sneaking into the gym through an open athletic department window, the entrepreneurial Irish realized that metropolitan college basketball had outgrown campus hoops facilities ("The Rumble," 2006). The following season, he began arranging and promoting college basketball matchups at "The Garden" with as many as three games per night (Irish, 1939, p. 36). Both Irish and the participating schools saw their profits skyrocket from the Garden's 18,000-plus seating capacity (Rosen, 1978).

While many games Irish hosted in these one-night stands displayed local metropolitan rivalries, others became known as intersectional games-pitting a local team against a visiting squad from another region of the country. One particular 
intersectional game in December 1936 brought Stanford coast-to-coast to play Long Island University (LIU), a team in the midst of a 42-game winning streak. Stanford's Hank Luisetti captivated the New York crowd with his skill, speed, and innovative one-handed shooting, scoring 15 points as Stanford ended LIU's streak, winning 45-31. The smitten press crafted Luisetti into a national hero for his efforts (Isaacs, 1975, p. 113).

Increased national interest in college basketball-in part due to these intersectional games - spanned from New York City to Stanford and many places in between. Kansas City, a geographic midpoint between the proven basketball establishment in New York and the innovative teams and players like Luisetti on the west coast, became an early basketball hotbed by hosting the Amateur Athletic Union's (AAU) national championship during much of the 1920s and 1930s.

Shortly after the AAU moved its tournament to Denver, and only months after Luisetti captivated the New York crowd with his one-handed jump shooting, Emil Liston, basketball coach at Baker (Kan.) University, created the first postseason college basketball tournament. The inaugural 1937 National Intercollegiate Basketball Tournament Championship in Kansas City pitted eight teams from small schools in South Dakota, Iowa, Kansas, Missouri, and Arkansas. The first tournament ended up being little more than a trial run for Liston's ultimate goal of a larger and more nation-wide competition. In 1938, Liston's dream of hosting a week-long 32-team tournament came to fruition. An estimated 15,000 total fans observed the beginnings of what became known as the National Association of Intercollegiate Basketball (NAIB) tournament in 1940 and subsequently evolved into the crown jewel of the National Association of Intercollegiate Athletics (Stooksbury, 2010, pp. 10, 12-13). While this tournament provided an introduction of postseason college basketball national championships, its impact on the major college basketball landscape remained relatively small (Morris, December 14, 1938).

Liston's tournament in the American heartland paled in comparison with a new undertaking in "Gotham." The Metropolitan Basketball Writers' Association (MBWA) partnered with Ned Irish in 1938 to create a postseason invitation-only tournament to cash in on big-time college basketball in Madison Square Garden. Six squads from top schools received invitations from the MBWA to the inaugural NIT. Throughout three nights more than 45,000 fans paid admission to watch "The Garden's" inaugural postseason gala, making the tournament an instant success (Irish, 1939, p. 36; Sheehan, 1938).

Coaches around the country took notice of this National Invitation Tournament. "Phog" Allen, Kansas University coach, protégé of basketball's founder James Naismith, and forefather of the National Association of Basketball Coaches (NABC) told an NIT official, "I think (the NIT) would be a very interesting experiment." Allen also remarked, "I believe the effort will go a long ways toward nationalizing the game and doing away with provincialism and sectional play" (Kerkhoff, 1996, p. 122). Allen continued by complimenting the NIT's main organizer and yet hinting at the sectional biases that plagued college basketball at the time, as he remarked, "Ned Irish has done a great job of building up basketball as a national sport in the minds of eastern people. Of course the western people have been conscious of this fact for years" (Kerkhoff, 1996, p. 123).

The success of the first NIT inspired the NABC to host its own championship tournament. Shortly after Temple defeated Colorado to win the 1938 NIT crown, Ohio State University coach Harold Olsen initiated an NABC discussion to hold 
its own postseason tournament. Olsen argued four key points that may have belied a hint of jealousy among the coaches' association toward the successful New York-based championship run by the writers' association. First, he highlighted a demand for a decisive national champion and, although two national tournaments already existed in 1938, he felt that the NABC was a more appropriate sponsor of such an event. Second, he cited the potential revenue generated from the event and its usefulness in the organization's efforts to promote the sport of basketball. In this line of reasoning, Olsen further justified his initial argument by indicating that in the NABC's tournament, "no outside promoters [would] get their first 'cut", (National Association of Basketball Coaches, 1938, pp. 150-51). Third, such a tournament would provide college basketball with greater representation at the next U.S. Olympic Basketball Trial tournament (see Cunningham, 2009 for more on the history of U.S. Olympic basketball). And fourth, the NABC should welcome a postseason tournament run in conjunction with its annual convention (National Association of Basketball Coaches, 1938, pp. 150-51).

The NABC agreed to Olsen's proposal and further suggested that the tournament be held under the auspices of the NCAA — an organization with which it sought and eventually gained alliance. Olsen presented the NABC's proposal to the NCAA executive committee in October of 1938. The NCAA accepted, placed Olsen at the head of the newly formed NCAA Basketball Tournament Committee, and charged him with creating a four-team Eastern regional tournament in Philadelphia and a four-team Western regional tournament in San Francisco. The Eastern and Western winners would meet near the middle for a championship game at Northwestern University (National Association of Basketball Coaches, 1938, pp. 150-51).

When this news became public, members of the MBWA expressed differing opinions on the NCAA's new postseason venture that seemed precariously similar to the NIT. Everett B. Morris, president of the MBWA, set a civil tone as he reported that the writers "adopted a resolution emphasizing the fact that their tournament was not, under any consideration, to be regarded as a rival to the proposed N.C.A.A. championship" (1939). Morris went so far in accommodating the NCAA tournament that he printed quotes from Olsen encouraging teams to pass over Morris' NIT for the new tournament. Olsen relayed the NABC and NCAA views on the matter by suggesting, "that (all NCAA member schools) refrain from promoting or supporting any other so-called 'intercollegiate basketball championship"" (December 13, 1938).

New York Times columnist and MBWA member Louis Effrat was less accommodating toward Olsen's brainchild. He believed that the creation of the NCAA tournament put the MBWA in an "uncomfortable position" (1938). By establishing a new national tournament, Effrat explained, the NCAA directly or indirectly pressured the writers' association to concede. Effrat noted that the MBWA did not want a reputation as "obstructionists" seeking "personal profit" (1938) even though they did profit financially from the success of their inaugural 1938 tournament. The writers' association promptly licensed a two-week study to determine the appropriateness of continuing the NIT. Results indicated willingness by enough colleges to send their teams to New York if invited, so the MBWA continued its tournament.

Despite the survey results, the writers still felt some pressure to discontinue their tournament. NCAA president-to-be Philip O. Badger explained the sentiment of many in the college basketball establishment to Ned Irish regarding this quandary. "I believe that the function of the writers is that of reporting the games 
and should not be that of promoting them. The conducting of tournaments in which college teams play should be in the hands of the colleges," (1939) Badger, a New York University (NYU) professor, argued. The MBWA took note and turned the management of the NIT over to a group of local college athletic administrators that formed the Metropolitan Intercollegiate Basketball Committee (MIBC). The writers remained involved in MIBC administration, yet they also pledged to "give the NCAA all the help possible in the conduct of its national championship tournament" (O'Riley, 1939). Ohio State's Olsen affirmed this stance in a report he gave to the NCAA at the end of 1938. In the same breath, Olsen also mentioned that the Metropolitan sportswriters would be terminating the NIT and joining with the new NCAA tournament (1938, p. 42) — an amicable arrangement that broke down, hinting at the changing attitudes that would eventually assist in straining the relationship between the two tournaments.

In 1939, the first NCAA tournament—run by the NABC-fell short of the concurrent second annual NIT on both attendance and profits, losing \$2,531 (National Collegiate Athletic Association, 1939, p. 116; Irish, 1940, p. 45). After this inaugural tournament, the NCAA Basketball Tournament Committee, comprised of NABC members, complained of "opposition in some quarters by other agencies interested in conducting so-called "national basketball tournaments'," and requested that the NCAA dictate that national championship tournaments should not be "in the hands of any outside promoters" (Report of Tournament, 1939, pp. 12, 14). Both statements seem to indicate that the NABC blamed the NIT and possibly even the NAIB championship for the NCAA tournament's financial losses.

Despite the NABC's excuses, many prominent coaches from the association had mixed feelings about renewing the NCAA basketball tournament. "There is some question about the advisability of us continuing," (Gretz, 1988) Olsen mentioned within months of his team's loss in the 1939 NCAA finals to Oregon. Howard Hobson, coach of the Oregon squad of "Tall Firs" who beat Ohio State in the inaugural championship, spoke even more bluntly fifty years later while recalling the feelings of the NABC membership after the first NCAA tournament lost money. "There was a lot of opposition going forward," (Gretz, 1988) he said, implying that, with the peak of the Depression still fresh in the national consciousness, the coaches' association despised the thought of being indebted to the NCAA or anyone else.

However the strongest voice in this discussion came from neither of the finalists. Kansas" "Phog" Allen persuaded the NABC to continue its championship and move the 1940 NCAA finals to Kansas City in hopes of improving its bottom line from the previous year's deficit. "You give me this tournament in Kansas City and I will not only pay back the deficit, but we will make you some money," (Kerkhoff, 1996, p. 124) he assured. Allen's confidence seemed well-founded, as Kansas City had become a respected host of basketball tournaments. The "City of Fountains" hosted the AAU national tournament from 1921 to 1934 and, after the construction of a new \$6.5 million Municipal Auditorium in 1936, hosted Liston's NAIB tournament from 1937 on (Stooksbury, 2010, p. 10). Allen, who had successfully organized both the so-called "world championship" in 1905 and the 1936 Olympic trials in Kansas City, seemed to care little that the NCAA championship would be competing directly with the more established NAIB tournament. 
However, the NIT presented a greater challenge. Although Allen initially showed interest in the NIT, the Kansas coach apparently no longer appreciated the New York tournament. Once the NABC-his organization-commenced its own tournament through the NCAA, the NIT became not just another tournament to him but a competitor. After the inaugural NCAA tournament's financial records came in with red ink, Allen made it his personal mission to see the continuation and success of the association's championship. Thus he sought loyalty to the NCAA tournament from coaches around the country to limit any stronghold the NIT might have outside of New York City. "If we could have half as good cooperation from the Eastern [NCAA] districts east of the Mississippi River as we have had from the Western half, the NCAA would overwhelm the whole country in basketball popularity," (Kerkhoff, 1996, p. 125) Allen stated in 1940, describing what may have been perceived as early battle lines between the two tournaments.

The 1940 NCAA tournament, under Allen's administration, benefitted from good luck that helped it generate \$9,522.55 (National Collegiate Athletic Association, 1940, p. 160). Allen's local Kansas Jayhawks reached the NCAA tournament finals, boosting local interest and attendance during the Western regional and in the finals against nearby Indiana University. Subsequently, Basketball Tournament Committee chair Olsen proudly proclaimed, "The success of this second N.C.A.A. tournament unquestionably establishes it as the outstanding basketball event in the country" (1941, p. 15). Olsen may have summarized the feelings of the NCAA and NABC, but he would have had difficulty convincing many others that his statement held any truth. For example, the New York-based NIT enjoyed a clear initial advantage over the NCAA tournament in many ways. Madison Square Garden crowds for the NIT outnumbered even a sold out Kansas City Municipal Auditorium. The NIT also treated its participating teams better. Not only did they get to visit New York City but the MIBC paid all expenses and gave a large percentage of the profits to each school after the tournament ended. In contrast, Allen had to beg the NCAA to reimburse the expenses of its participants and the NCAA's parting gift to each team was only a fraction of the NIT payout (Kerkhoff, 1996, pp. 127-28).

Further, the NIT prospered from its local talent at schools such as St. John's, NYU, LIU, and City College of New York (CCNY) which had produced many of the top players, coaches, and teams in college basketball's early decades. The NIT, with its avid local basketball fan base continually filling the spacious Madison Square Garden, served as a showcase event for New York schools and their elite invitees. Therefore, while the NCAA tournament was growing in prestige and profits in 1940, it still may not have matched that of its older counterpart.

\section{Sport for Charity}

The growing prestige of college basketball postseason tournaments continued as the United States entered the Second World War. Only months after Japan's attack on Pearl Harbor, and shortly after the 1942 college basketball postseason tipped off, an avid local basketball fan wrote to the New York Times complaining that the top two metro teams of that season-CCNY and LIU—did not get a chance to play against each other (Simon, 1942). LIU rarely scheduled local fives in the regular season and both teams lost in the first round of the NIT. The fan proposed 
that the two teams face-off in a game for charity. John Kieran, the sports editor of the paper, responded in favor. Within a week the game materialized, pitting the two bitter metro rivals ("L.I.U. Five," 1942). "It took a war to get them together," (March 28, 1942) Kieran proclaimed of the ad hoc game in which proceeds aided the Army Emergency Fund.

Sport for charity became a popular way to finance American war aid organizations in the early 1940s. As the CCNY-LIU charity match drew 16,251 fans to Madison Square Garden and generated more than \$7,000 for the Army Emergency Fund, many entrepreneurs saw the value of organizing spectator sporting events in the name of charity during the Second World War (Coffey, 1943, p. 82). Many of these producers showed little altruism, though, by commonly increasing ticket prices and often taking a cut of the proceeds before handing the rest to charity ("Red Cross Game," 1943). The Red Cross remained skeptical of this method of fundraising at the onset of World War II. The aid organization had negative memories of previous sport for charity in which promoters and private groups "chiseled" the profits from boxing matches held in its name. Kieran lamented that in these events, "Charity got everything except the money" (January 27, 1942).

Nevertheless, during World War II the Red Cross attached its name to sporting events only if event organizers did not deduct any expenses from the total receipts. This all-or-nothing stipulation prevented many individual sport athletes from competing for the Red Cross because they usually sought reimbursement at least for their transportation and lodging (Kieran, January 27, 1942). Attitudes changed, though, as Sonja Henie began what became a litany of Red Cross sporting events-despite the all-or-nothing philosophy_-with a January 1942 figure skating matinee at Madison Square Garden in which the Red Cross received every penny of the gate receipts. The Red Cross sporting events that followed became so lucrative throughout the war that metropolitan sportswriters organized a sports committee of the New York City Red Cross chapter to aid in the organization's fundraising efforts ("Red Cross Names," 1945). In 1944, the sports committee raised $\$ 1,086,155.68$, surpassing its goal of \$1 million in contributions to the Red Cross' \$200 million national goal. In 1945 , the sports committee raised $\$ 701,978.01$, surpassing its target of $\$ 500,000$ by $40 \%$. Although the 1945 campaign listed events in all twenty sports it had endorsed in 1944, the scaled back fundraising goal was "due to war conditions" and the prediction that "sports will be curtailed" ("Red Cross Reports," 1946).

Throughout the Second World War, Americans donated generously to war aid organizations. As a primary beneficiary of this magnanimity, the Red Cross proclaimed that it received "the greatest freewill offering in history" as almost $\$ 785$ million rolled in from 150 million individual donations between 1942 and 1946 (American National Red Cross, ca. 1947). The Red Cross, an organization that relied mainly on membership and subscriptions to raise money, stated in 1945 that, "No other single cause save that of the country itself has received contributions that approach such magnitude. The membership is greater than the votes cast by either of our political parties in the 1944 Presidential election or than the membership of any of our great religious faiths" (Dulles, 1950, p. 363). Clearly, Americans proved their willingness to share in the war burden through direct contributions to the Red Cross.

With their attendance at Red Cross sporting events, Americans also proved their interest in sport spectatorship even through difficult times. The 1942 postseason Army Emergency Fund matchup between CCNY and LIU struck a chord 
with metro basketball promoters, notifying them of the compatibility between the public's penchant for elite sporting events and its willingness to donate to worthy causes. The CCNY vs. LIU matchup set the direction in which college basketball would raise funds for charity during World War II.

In Kieran's promotion of the 1942 CCNY-LIU contest, the future Red Cross sports committee member casually suggested in his weekly column that the NCAA and NIT champions meet for the "all-out college championship of the basketball year" (March 28, 1942) with the profits going to the Red Cross. Kieran's continued evangelism for this matchup gathered steam and the New York Times featured discussions throughout the 1942-43 basketball season about the possibilities of scheduling "The Red Cross War Fund Benefit Game" after the postseason tournaments ("Red Cross Game," 1943).

In January of 1943 the New York Times announced that the NCAA and Ned Irish agreed that Madison Square Garden would host - for the first time - the ensuing NCAA Eastern Regional and tournament final. The shared site of the NIT and NCAA tournament finals meant that the championship teams of both tournaments would be in New York City at the end of March 1943, simplifying the logistics of the Red Cross War Fund Benefit game. Sportswriter Kingsley Childs stated (1943) that the NCAA's change in venue from Kansas City to New York City "was made largely in the interest of transportation conservation and with an eye toward sparing the four Eastern regional participants the problem of traveling to and from Kansas City." However, since only two of the eight finalists in the NCAA tournament's first four years would have had to travel farther to Kansas City than New York City, this rationale for relocation seemed to lack substance. Childs also opined, in what became an accurate prediction, that the NCAA's change would probably benefit the organization financially. Nevertheless, the New York Times announced in February that both tournaments and Ned Irish pledged their total cooperation for the 1943 Red Cross War Fund Benefit game ("Red Cross Game," 1943).

\section{The Red Cross War Fund Benefit Games}

Red Cross officials expressed gratitude to Irish and the two tournaments when the initial Red Cross game featuring 1943 NCAA champion Wyoming and NIT champ St. John's netted \$24,256.06 for the organization (Irish, April 21, 1943). More than 18,000 fans entered Madison Square Garden to watch the lanky and sharpshooting westerners defeat the local Redmen on April 1, 1943 (Ditman, April 22, 1943). With two minutes left in regulation, Wyoming held a seemingly insurmountable eight-point lead. But after a set play, a rebound put-back, two free throws, and a fast-break layup St. John's had tied the score. In overtime the veteran Cowboys regained control for the victory (Effrat, 1943). While heaping praises on the swashbuckling one-handed shooters from Wyoming, the New York Times bemoaned, "It was unfortunate that St. John's chose the last game of the year to be at its poorest" ("Game Nets," 1943). The handsome proceeds of the game, which included a \$1,000 winning bid for the game ball, helped make this game's donation the largest single gift to the Red Cross in the metro area at the time.

The 1944 contest exhibited similar excitement and even greater profits. NCAA titleholder Utah and back-to-back NIT victor St. John's raised \$44,454.68 ("Red 
Cross Reports," 1946). In a twist of fate, Utah originally traveled to New York City to enter the NIT and lost in the first round. On the eve of their return trip west, the NCAA asked if they would replace Arkansas, a team incapacitated from an automobile accident, in the other national championship tournament. Utah obliged and headed back to New York City to win the NCAA tournament and upset the "favored" (Richardson, 1944) NIT champion St. John's in the second Red Cross game. The Utes had an exceptionally young and tall team-averaging 18.5 years old and 6'3" tall. Freshman Arnie Ferrin's scoring led the Utah offense while Japanese-American freshman Wat Misaka - the Utes' shortest player at 5'8"- - helped the defense hold the Redmen to what sportswriters considered uncharacteristically poor shooting that impacted the outcome of the game (Effrat, 1944).

While these first two Red Cross games displayed exciting basketball and brought in princely profits, speculation arose that the Red Cross was not the only entity seeking financial gain from college basketball. In the fall of 1944, Utah coach Vadal Peterson revealed that a gambler came to his hotel room in New York City the morning of the NCAA championship asking him to throw the game. Peterson boasted that he swiftly dismissed the reprobate. This claim became only a small part of the growing speculation that gamblers were infiltrating college basketball by fixing games at Madison Square Garden. Peterson's account also came on the heels of a bold public proclamation by "Phog" Allen that he knew of two players whom gamblers caused to throw basketball games in eastern collegiate tournaments ("Coach's Cry," 1944). This pronouncement partially targeted Ned Irish and the Madison Square Garden-hosted NIT. Irish telegraphed Allen in response asking for any proof of the accusatory claim ("Ned Irish," 1944). Allen produced one name, a Temple player whom sources told him had shaved points during a 1943 game. Irish responded that the player in question did not even attend the particular game. Philadelphia reporters corroborated Irish's rebuttal (Kerkhoff, 1996, p. 142).

Nevertheless, Irish admitted that gambling had become an issue in his venue, and also insinuated that he did not need Allen pointing out the problems in New York from Kansas. In fact, by 1944 Irish had blacklisted a number of gamblers from college basketball games at "The Garden." Allen, the instigator of this heated public discussion, received harsh rebukes for his accusations-especially from his friend and fellow Kansan, Emil Liston, founder of the NAIB tournament. Liston, whose tournament publicized the morality and character of its participants, argued that Allen should have faith in the loyalty of college basketball players and their coaches ("Coach's Cry," 1944; Rosen, 1978, p. 29). Liston's charge demonstrates the increasingly divergent perspectives among Irish, the host of a tournament in New York City in which he had to continually guard against gambling; Liston, the host of a tournament of small schools in Kansas City that evaded the influence of gamblers and promoted sportsmanship and character; and Allen, a coach who experienced the big-time basketball culture in both the "Heartland" and the "Big Apple."

Based on these impassioned exchanges among the key administrators of the three college basketball tournaments, the 1944-45 season transpired with a shadow of gambling speculation looming over New York City. In January of 1945, the speculation became fact. Five Brooklyn College players admitted to colluding with gamblers on their games. The players received quick expulsion and the season continued in New York City with intersectional regular season matchups 
at Madison Square Garden and teams vying for spots in postseasons tournaments (Rosen, 1978, p. 29).

Two months after the Brooklyn College incident, newspaper columns anticipated potential postseason selections and matchups. The New York Times printed a short article that provided interesting insight regarding the status of the two championships. The daily indicated that many teams who could potentially get bids to enter either the NIT or NCAA tournaments would probably choose the NCAA tournament "because it involves stronger competition" ("Tennessee Becomes," 1945). While the NCAA and NABC had clearly espoused this view since their tournament turned a profit in 1940, it seems unusual that the leading news publication in New York City — which would have been allied with the MIBC_-would make that claim. The sentiment behind this New York Times comment may have implied that the NCAA champion had defeated the NIT champion in the Red Cross game the previous two seasons, providing hard evidence of a possible pecking order. Yet the circuitous postseason run that Utah made in 1944-losing in the first round of the NIT, winning the NCAA tournament, and then beating the NIT champion in the Red Cross game-seemed to give the NIT grounds for questioning the reliability of one game determining tournament prowess.

Even though the relative status of the two championships may have remained somewhat unclear, the Red Cross game of 1945 arrived featuring the champions of two increasingly popular tournaments. Without a local participant for the first time, New York basketball faithful filled "The Garden" for a highly anticipated matchup. Oklahoma A \& M and its seven-footer Bob "Foothills" Kurland won the 1945 NCAA tournament, setting up a "Battle of the Skyscrapers" with NIT champion DePaul and its 6'10" George "Hi-Ho" Mikan (Richardson, 1945). "Mountainous Mikan and Kolossal Kurland" came to Madison Square Garden with heaps of hype, but the game did not live up to its billing. Hampered by an ankle injury, Mikan fouled out only 14 min into the game and Kurland's Aggies coasted to victory from there (Effrat, 1945). Although fans did not get to see much of the anticipated low post battle and without a local team to support, the game still generated $\$ 48,499.73$ for the Red Cross War Fund, including an \$8,000 bid for the game ball at halftime that bumped the overall donation above that of the previous year's Red Cross game (“Basketball Makes," 1945; Cohane, 1946, p. 33).

Discussions after the war about the potential for a fourth installment of the Red Cross "mythical national championship" game in 1946 proved fruitless (Effrat, 1946). While no NCAA, NIT, or Red Cross organizers gave official reasons, one coach remarked that "the proposal to stage the game was not advanced until too late to permit satisfactory arrangement" (Strauss, M., 1946). Instead, Madison Square Garden and the Red Cross hosted a benefit game featuring the AAU national champion Phillips 66 "Oilers" of Oklahoma and a quintet of collegians from the New York Athletic Club. This game failed to capture the hearts and pocketbooks of local fans like the previous college matchups, attracting a Madison Square Garden season low 6,734 fans and raising only \$12,000-less than one-fourth of the 1945 purse. The paying public clearly valued a championship of champions that seemingly meant something in the world of college basketball rather than a random amateur matchup. They also found less motivation to donate money to war funding agencies after D-Day. By all measuring sticks, this event was unsuccessful, but it did not undermine the fact that the NCAA-NIT charity match-ups provided 
generous donations to the Red Cross' war efforts. With the three college basketball games and their undercard events as the only Red Cross-sponsored hoops affairs, basketball became the third leading sport in the Red Cross War Fund drives during World War II behind horse racing and baseball ("Red Cross Reports," 1946).

\section{The NCAA-NIT Relationship}

While the impact of these games on the Red Cross was obvious, these three "mythical national championships" also had an impact on the nature of college basketball's postseason. The creation of the NIT in 1938 and the NCAA tournament in 1939 helped nationalize college basketball even though the tournaments operated differently. In its early years, the NCAA tournament appeared more ecumenical by inviting one team from each of the association's eight districts across the country (Olsen, 1940, p. 9). The NIT did not invite teams with much regard to geography-it simply sought the best teams. Early invitations reached as far west as the Rocky Mountains, and two metro teams always received bids until 1944 when only one team represented "Gotham" (Sheehan, 1938; Daley, 1939; Daley, 1940; Daley, 1941; Daley, 1942; Childs, March 12, 1943; Strauss, E., 1944).

The proudly New York-based championship took pride in the talent of local New York teams, the massive Madison Square Garden, the enthusiasm of the dense population, and the powerful media. Ned Irish proved earlier in the 1930s that this combination made for good basketball and good profits. The perpetuation of intersectional games at "The Garden" reinforced that New York City had something attractive about its basketball that no other area did. The local press and local teams believed that the attraction was, at least in part, due to the local talent (Kieran, February 22, 1942). Ned Irish quantified this claim, proudly circulating statistics showing that New York City teams won more games than they lost against intersectional visitors to Madison Square Garden from 1938 to 1941. Thus, for many, basketball's epicenter of popularity and talent landed within the five boroughs (Irish, 1942, p. 94).

While New York City enjoyed status as a basketball hotbed for many reasons, the rest of the country was not willing to concede that the metro area housed the best basketball talent. Realistically, since college basketball remained somewhat regional at this time, no one district, conference, or tournament could definitively claim top status. Although the popular belief today is that the NIT was the primary event and the NCAA tournament ran secondary at least until the 1951 gambling scandal, that hierarchy may be difficult to prove. In 1939, after the inaugural NCAA tournament and the second annual NIT, the latter was clearly superior as NCAA organizers scrambled through only five months of preparation to put on a geographically-equitable tournament that lost money. By 1940 the NCAA tournament was profitable but the NIT still paid its participants better than the NCAA. By 1943 the NCAA shared the prestigious venue and accompanying profits of Madison Square Garden with the NIT, making it difficult to determine which tournament pulled rank. Further, as the Red Cross games unfolded, metropolitan basketball fans steeped in the glorified history of New York City hoops received a heavy dose of the rich basketball traditions outside "Gotham" as not one NIT or metropolitan team won a Red Cross game.

Ray Meyer, coach of the losing DePaul team in the 1945 Red Cross game, recalled the significance of the charity hoops events when he said, "They weren't 
just benefit games... they were really the games for the national championship" (Gretz, 1988). While the coaches, players, and fans may have echoed this sentiment, administrators of neither tournament seemed interested in touting these games as true national championships. The NCAA, as three-time champs, would have been the natural organization to boast of its victories. Yet doing so would have meant acknowledging the NIT as an equal and admitting that the game of champions-and not its own tournament - produced the true national champion. Instead, the NCAA Basketball Rules Committee focused its formal reports on recapping the games and reinforcing the powerful philanthropy the games generated. The committee briefly provided 1943 and 1944 game summaries (Olsen and St. Clair, 1944, p. 55; Olsen and St. Clair, 1945, p. 54), but failed to even mention the 1945 game (Olsen and St. Clair, 1946, pp. 38-49). Sportswriters allied with the MIBC and NIT responded similarly by filling their pages with postgame accounts, noting that while the St. John's losses in 1943 and 1944 came as surprises, they also raised huge sums of money for the Red Cross (Danzig, 1945).

Indeed, NIT and NCAA tournament administrators kept their public comments diplomatic and, in most cases, charity-focused. This may have been because they believed or wanted the public to believe that the Red Cross games were fundamentally charity-driven with the outcome as a clear second priority. While charity may have nominally been the top priority, Meyer's description of the games' meaningfulness clearly underscored the competitiveness of the matchups. Based on the results of the Red Cross games as "mythical national championships," the NCAA would have some evidence that it was superior to the NIT at that time.

The NCAA's reluctance to boast about its apparent superiority may have originated in part from its reliance on the lucrative box office receipts of tournament games held at the gigantic Madison Square Garden — home of the NIT and prized venue of the MIBC. Indeed, Madison Square Garden helped the NCAA match the NIT's average attendance figures and exponentially increased the collegiate association's profits. In Kansas City, the 1942 NCAA tournament made \$1,361.85 (National Collegiate Athletic Association, 1942, p. 103). In 1943, the first year in which "The Garden" hosted NCAA tournament games, the association's tournament profits increased more than sevenfold to $\$ 10,199.89$ (National Collegiate Athletic Association, 1943, p. 79) and more than $150 \%$ the following year to $\$ 26,029.29$ (National Collegiate Athletic Association, 1944, p. 167). The NCAA stuck with this profitable venue even as speculation of gambling and point-shaving in the arena became fact in early 1945 . That year, NCAA tournament profits increased slightly (National Collegiate Athletic Association, 1945, p. 167) and almost doubled again after the war in 1946 to $\$ 50,664.33$ (National Collegiate Athletic Association, 1946, p. 167). Legendary California coach Pete Newell conveyed the ambivalent attitudes of the NCAA toward the lucrative venue as he reminisced that "a lot of people didn't like the idea of playing in New York, but there is no question it helped establish the tournament" (Gretz, 1988).

The lure of money in "The Garden" overtook the risk of playing in a venue associated with low morals and gamblers. By 1951, when the NCAA stripped Madison Square Garden of the finals during the impending gambling and point-shaving trials, the NCAA's profits had increased to $\$ 104,994.03$ (National Collegiate Athletic Association, 1951, p. 247) — largely because of the fame it amassed in Madison Square Garden and New York City. Had the NCAA boasted in the mid-1940s that it was the better tournament, it may have risked losing its welcome (and increasing 
profits) in New York City. The eventual decision to move the 1951 finals to Minneapolis showed that the NCAA felt confident at that time that it had a quality basketball tournament that did not need New York City to thrive. After 1951, the NCAA did not hold tournament games in "Gotham" again until it scheduled first round games there from 1955 to 1961.

\section{Ned Irish's Involvement}

Clearly the NCAA had to make difficult decisions regarding the irresistible financial incentives and repulsive moral drawbacks associated with basketball at Madison Square Garden. In the minds of many NABC and NCAA officials, Ned Irish created both of these good and evil outcomes. The basketball promoter's marketing skills drew sell-out crowds and large profits for NCAA teams at his venue and yet, whether fairly or not, he also drew criticism for the gambling and point-shaving that occurred at his venue. NIT officials, with much more nuanced understandings of the complexities of college basketball in New York City, spent much less time pinpointing Irish as either the hero or the scapegoat of college basketball at "The Garden." Nevertheless, as the director of basketball at the host venue for both championships, Irish became very involved in the NIT and NCAA tournaments during the Red Cross games and the relative amicability of the tournaments during the 1940s.

Irish's relationship with the NIT remained explicit and seemed generally agreeable. He relied on the local sportswriters allied with the MIBC (which later changed its name to the Metropolitan Intercollegiate Basketball Association-MIBA) to cover the college basketball games he hosted, including the NIT. The MIBC, in turn, relied on the availability of his large venue and his promotional talents to draw the box office receipts that led to the NIT's profitability. As a fellow New Yorker and ex officio member of the sports media, he maintained loyalty to the NIT.

Irish's relationship with the NABC may not have been so explicit, but it had similarities. Future NCAA president Badger described the promoter's feelings by proclaiming that "(Irish) is anxious to cooperate ... with the N.C.A.A. in every way possible and realizes that in certain respects the future of the intercollegiate basketball program at the Garden is related to the matter of maintaining friendly relations with (the NCAA)" (Badger, Ohio State Director of Athletics File, Badger to H.G. Olsen, February 23, 1940). While Irish relied on these friendly relations with universities and their basketball teams to fill his schedules, he also took specific interest in the coaches' association, serving as the editor of its yearly catalog in 1941 and 1942. Not surprisingly, Irish won the NABC's annual Metropolitan Intercollegiate Basketball Committee Award in 1942 for his "outstanding contributions" (National Association of Basketball Coaches, 1967, pp. 69-70) to college basketball. The MIBC made the award possible beginning in 1941 but left it up to the $\mathrm{NABC}$ to determine the recipient and organize the presentation. Therefore, the NABC and MIBC clearly recognized and valued Irish's contributions to their efforts. The award further proves that the two tournament organizing committees had some cooperation.

Irish's good-standing relationship with the NABC, the NCAA, and its member schools filled his pockets during the war through popular intersectional regular season games and NCAA tournament games. Despite this good wartime stand- 
ing, NCAA and NABC officials directed their prewar disapproval of the "private interests" of the NIT and many of their petty grievances after the war at Irish as the de facto face of the NIT. Many coaches knew that he stood to profit as much as anyone from hosting championship tournaments at "The Garden." Indeed, Irish testified in 1945 that on top of his salary he received $10 \%$ of the profits of every basketball game he hosted at Madison Square Garden-a financial sum he was unwilling to disclose ("Irish Draws," 1945).

In the years after the war, as the evidence mounted of widespread gambling and point-shaving in college basketball games at Irish's venue, his good-standing - and, by association, that of the NIT - with the NABC and NCAA diminished, but the NCAA continued to use "The Garden" to increase its tournament profits. In 1951, New York State authorities uncovered hard evidence of point shaving in games that occurred in New York City. Madison Square Garden, both championship tournaments, and, to an extent, Ned Irish came under deep public suspicion as local courts prosecuted 32 players including those from NIT or NCAA championship teams in 1948, 1949, 1950, and 1951 (Rosen, 1978, pp. 136, 189, 202).

\section{The NCAA-NIT Relationship After the Scandal}

Although the NCAA and NIT shared Madison Square Garden and Irish for much of the prescandal era, they differed on many organizational principles that led to antagonism after the scandal. Some of these differences came about with the selection of teams. The NCAA tournament district selection committees sifted through multiple conference champions and talented independent teams to choose the representative from each district. Some districts hosted playoffs to determine their champions and the district selection committee decided autonomously in others (Olsen, 1940, p. 9). In 1951, the NCAA doubled its field to 16 teams, offering automatic qualifying bids to the championship teams of conferences in good standing with the NCAA's stringent policies, and filling the brackets with at-large bids to top independent teams and conference "also-rans" (National Collegiate Athletic Association, 1951, p. 247). This method, which continues today, favors conference teams over independents. However, this favoritism did not result in unilateral action against independents during the NCAA's early years, as the eightteam NCAA tournament fields between 1939 and 1950 included as many as three non-conference-affiliated teams in a given year. After 1951, independent teams began to respond to this perceived conference bias. By 1957, ten independent teams had accepted invitations to the NIT without regard to the NCAA's timeline of extending at-large bids (NCAA University Basketball Tournament Committee, 1957, pp. 3-4). This indicated, to some extent, that teams still valued NIT bids and were unwilling to wait and see if the NCAA would select them alongside the automatically qualifying conference champions even if the conference winners had worse records or played weaker opponents. It also may have been the case that independent teams entered the NIT early as a protest against NCAA tournament policies. Still others who resided in metropolitan New York may have simply sought "home court" advantages.

Throughout the ensuing decades the NCAA used its growing influence as the association representing the interests of college and university athletic departments 
across the country to coax these schools and their conferences into choosing its tournament over the NIT. In 1954, the NCAA Basketball Tournament Committee noted "friction" (p. 2) with the NIT and recommended "that the NCAA take aggressive and positive action in encountering the NIT's effort to disparage and compete with the National Collegiate Tournament" (p. 2). The Committee's recommended action included publicity, earlier selection of at-large teams, and "efforts to dissuade allied conferences from permitting their 'also-ran' teams from competing in the NIT" (the committee singled out the Mountain States, Mid-American, and Missouri Valley Conferences as perpetrators of this offense) (p. 2).

In 1955, the NCAA Basketball Committee suggested to the Executive Committee that it disallow conference "also-ran" teams from playing in the NIT (p. 3). The following year, the newly named University Basketball Tournament Committee asked the NCAA Executive Committee to "redouble its efforts" in that regard and attempt to garner some loyalty from independent teams (p. 6). In 1957 the NCAA sent a letter to the ten independent schools that chose the NIT over the NCAA, but made little headway in seeking their allegiance (NCAA University Basketball Committee, p. 3). In 1960, the committee proposed ineligibility for schools not supporting the NCAA tournament and proposed putting independent teams across the country into geographical groupings to increase the objectivity of potential NCAA at-large bids for these teams (p. 3-4). In 1961, the committee proposed to the MIBA the possibility of the NIT becoming a qualifying or first round tournament for the NCAA championship. "It was generally agreed," the NCAA committee's negotiator noted bluntly about the NIT's response to the NCAA's condescending proposal, "that a reorganization of the NIT along the lines envisioned would not be accomplished in the immediate future" (p. 4). The committee also proposed that year that the NCAA place a one-year ban on any athletic program that accepts an NIT bid instead of an NCAA bid (p. 5).

By 1962, the NCAA University Basketball Tournament Committee accused three schools-Loyola (Ill.) University, University of Houston, and St. John's University —of violating its proposed hard line stance regarding participation in the NIT. The NCAA Executive Committee, however, took a softer stance. Instead of an NCAA ban on teams that did not support the tournament by disregarding and NCAA bid and entering the NIT, NCAA Executive Director Walter Byers negotiated a deal with the NIT that began the definition of a clear hierarchy between the two championships. In this agreement neither tournament would have any contact with potentially invited schools until a proposed date in February of 1962. On that date, the NCAA would issue its at-large bids at 10:00 a.m. The NIT, in turn, could not invite any teams until 11:00 a.m., giving the NCAA a head start to attract the top teams (NCAA University Basketball Tournament Committee, p. 2, Appen$\operatorname{dix} B)$.

As the NCAA continually added member institutions and their athletic conferences, the association began to more effectively coax teams across the country to follow its rules and join its championships. Byers used this increasing power while promoting the drawbacks to the NIT's big-city, off-campus, privately-run model as he negotiated a clear advantage for the NCAA over the NIT in the 1962 deal. Through this agreement, the NCAA continued its hold on conference champions who received automatic qualifying bids, and, more importantly, also got the first shot at conference "also-rans" and independent teams. The silver lining for the NIT was that any school entering its tournament through this deal did not have 
to worry about potential NCAA sanctions or NABC reprimand for doing so. The two tournaments renewed this agreement annually until 1968 when the NCAA negotiated a two hour head start, inviting teams at 9:30 a.m. while the NIT had to wait until 11:30 a.m. (NCAA University Basketball Tournament Committee, p. 7). By 1975, defending NCAA champion North Carolina State's all-American David Thompson gave voice to what had become a distinct status disparity between the two tournaments. In lamenting his team's failure to earn an NCAA bid and relegation to the NIT, Thompson called the New York-based championship, "a loser's tournament" (Goldaper, 1975).

\section{Conclusion}

Thompson's remark implies the NCAA basketball tournament's continually growing status in the world of college basketball. The "winner's tournament" made a number of timely changes in the 1950s and 1960s that allowed it and the entire NCAA to grow in profits and status. During this time, the NCAA continually added schools to its membership and observed many of its members obtain conference affiliations. In 1956 only 45 of the NCAA's 160 University Division (what became Division I) teams remained independent of any conference ties. This number lessened over a period of time that saw the NCAA basketball tournament's automatic qualifying bids to conference champions rise from ten in 1951 to thirty-one automatically qualifying conferences today. Thus, the NCAA's stronghold on conference champions came to represent the elite of a greater number of teams across the country (NCAA National Collegiate Basketball Tournament Handbook, 1956, p. 2).

As the NCAA's jurisdiction extended through its growing membership, so did its ability to attract media outlets that popularized its events. In 1946 the NCAA championship game was televised for the first time by a local New York City CBS affiliate. In 1952 tournament games came on screen to regional audiences for the first time. The 1954 championship was the first one aired to a national audience. By 1957, coverage of the finals included 11 television stations and a live radio broadcast through 73 stations in 11 states. In 1963 the NCAA signed a $\$ 140,000$ television contract with "Sports Network" to broadcast the championship game for six years. When that contract expired, NBC took over the rights to the championship, paying $\$ 547,500$ in 1969 . Television audiences grew rapidly over the next four years, encouraging NBC to pay $\$ 1,165,755$ in 1973 to air the championship game. This championship game, the first televised in prime time, attracted 39 million viewers in 13,580,000 homes (Smith, pp. 182-187).

While the NIT stayed profitable and remained a viable secondary postseason option for college basketball teams, its second-class status became more distant after Thompson's remarks. The "loser's tournament" hosted a healthy 32 teams in 1975, but the NIT's value had not appreciated through national television contracts of the NCAA's magnitude. While the NCAA also hosted 32 teams in 1975, during the next decade it doubled its entrants and saw its television profits skyrocket while the NIT plateaued at 32 and lost its television contract in 1985. Complaints from the NIT that the larger tournament was trying to monopolize the industry and put it out of business did not reach the courtroom until 2005 (Litsky, 2005). This litigation came too little and too late, though, as the NCAA had become too powerful to overcome in court and public opinion - thanks in large part to its growing basketball tournament. 
The NCAA's status jump over the NIT and its eventual market domination began well before NIT protests in 1985 turned to legal battles twenty years later. From the beginning, the NCAA tournament's philosophy of inviting teams in a geographically equitable manner and leaving administrative duties in the hands of college employees was more pleasing to the colleges. However, this vision alone was not enough to produce good results. By sharing Madison Square Garden with the NCAA beginning in 1943, the NIT gave the NCAA a foot in the door to potentially equal the New York-based tournament's status and profits. Using Ned Irish's promotional work, the NCAA tournament's status and profits grew. The NCAA built on the momentum of three consecutive Red Cross "mythical national championship" game victories over the NIT, eventually outmaneuvering the NIT by adeptly avoiding permanent damage from the 1951 gambling and point-shaving scandal and adding more teams to take over available market shares of the public's increasing appetite for postseason college basketball in the decades following the scandal. As a fitting end to the slow rise of the NCAA tournament as college basketball's premier postseason event and the NIT's slow fall into insignificance, both tournaments now operate under the authority of the NCAA.

\section{References}

American National Red Cross. (ca. 1947). The Greatest Freewill Offering in History. Washington, D.C.: The American National Red Cross.

Badger, P.O. (1939, March 13). [Letter to Ned Irish]. Ohio State University Archives (Director of Athletics Series (9/3-1/13), National Collegiate Athletic Association: Basketball Tournament: 1938-1941 File). Columbus, OH.

Badger, P.O. (1940, February 23). [Letter to Harold Olsen]. Ohio State University Archives (Director of Athletics Series (9/e-1/13), National Collegiate Athletic Association: Basketball Tournament: 1938-1941 File). Columbus, OH.

Basketball Makes Contribution to Red Cross. (1945, April 13). The New York Times. Retrieved at http://www.proquest.umi.com

Childs, K. (1943, January 21). N.C.A.A Will Hold Court Play Here. The New York Times. Retrieved at http://www.proquest.umi.com

Childs, K. (1943, March 12). Manhattan, W. and J. Quintets in Invitation Tourney; N.Y.U. in N.C.A.A. Event: Fields Completed for Garden Play. The New York Times. Retrieved at http://www.proquest.umi.com

Coach's Cry of Gaming Peril Draws Rebuke. (1944, October 22). The Chicago Tribune. Retrieved at http://www.proquest.umi.com

Coffey, J. (1943). National Invitation College Tournament. In O. Tower (Ed.), The Official National Basketball Committee Basketball Guide, 1942-43 (pp. 82). New York, NY: A.S. Barnes.

Cohane, T. (1946). Oklahoma Aggies Take Red Cross Classic. In O. Tower (Ed.), The Official National Basketball Committee Basketball Guide, 1945-46 (pp. 33). New York, NY: A.S. Barnes.

Cunningham, C. (2009). American Hoops: U.S. Men's Olympic Basketball from Berlin to Beijing. Lincoln: University of Nebraska Press.

Daley, A.J. (1939, March 24). Lloyd of St. John's Honored with L.I.U.: He is Chosen as Outstanding Player of Basketball Tourney in Garden. The New York Times. Retrieved at http://www.proquest.umi.com

Daley, A.J. (1940, March 12). Duquesne and DePaul Gain Semi-Finals on Garden Court: St. John's Quintet Eliminated 38-31. The New York Times. Retrieved at http://www. proquest.umi.com 
Daley, A.J. (1941, March 19). Ohio U. and C.C.N.Y. Win as National Invitation Basketball Starts at Garden: 15,751 See Beavers Stop Virginia, 64-35. The New York Times. Retrieved at http://www.proquest.umi.com

Daley, A.J. (1942, March 20). C.C.N.Y. Five Upset by Western Kentucky; Toledo Wins; Beavers Toppled in Garden by 49-46. The New York Times. Retrieved at http://www. proquest.umi.com

Daley, A.J. (1945, March 29). Sports of the Times: Paging Jack-the-Giant-Killer. The New York Times. Retrieved at http://www.proquest.umi.com

Danzig, A. (1945, March 5). Sports of the Times: Sports and Its Red Cross Record. The New York Times. Retrieved at http://www.proquest.umi.com

Ditman, A.J. (1943, April 22). [Letter to Robert Shepard]. National Archives and Record Administration II (Records of the American National Red Cross, Collection \#ANRC, Central Files, 1881-1982 (1935-1946 Segment), 224 Sports Benefits Basketball). College Park, MD.

Dulles, F.R. (1950). The American Red Cross: A History. Westport, CT: Greenwood Press.

Effrat, L. (1938, December 21). On Basketball Courts. The New York Times. Retrieved at http://www.proquest.umi.com

Effrat, L. (1943, April 2). 18,316 See Wyoming Quintet Beat St. John's in Overtime. The New York Times. Retrieved at http://www.proquest.umi.com

Effrat, L. (1944, March 31). Utah Trips St. John's Five in Meeting of Champions for Red Cross. The New York Times. Retrieved at http://www.proquest.umi.com

Effrat, L. (1945, March 31). Basketball Fans Differ on Mikan. The New York Times. Retrieved at http://www.proquest.umi.com

Effrat, L. (1946, January 28). Basketball Fans Here Speculate On Fate of Annual Play-Off Game. The New York Times. Retrieved at http://www.proquest.umi.com

Fitzpatrick, F. (2000). And the Walls Came Tumbling Down. Lincoln: University of Nebraska Press.

Nets, G. \$26,244 for Red Cross Here. (1943, April 29). The New York Times. Retrieved at http://www.proquest.umi.com

Goldaper, S. (1975, March 10). North Caroline State Snubs N.I.T. The New York Times. Retrieved at http://www.proquest.umi.com

Gretz, B. (1988). Phog Allen helps save early event. The Houston Chronicle. Retrieved at http://infoweb.newsbank.com

Irish Draws 10\% of Games' Profit. (1945, March 29). The New York Times. Retrieved at http://www.proquest.umi.com

Irish, N. (1939). Basketball in Madison Square Garden. In O. Tower (Ed.), Spalding's Official Basket Ball Guide, 1938-9 (pp. 36). New York, NY: American Sports.

Irish, N. (1940). Basketball in Madison Square Garden. In O. Tower (Ed.), Spalding's Official Basket Ball Guide, 1939-40 (pp. 45). New York, NY: American Sports.

Irish, N. (1942). Basketball in Madison Square Garden. In O. Tower (Ed.), The Official National Basketball Committee Basketball Guide, 1941-42 (pp. 94). New York, NY: A.S. Barnes.

Irish, N. (1943, April 21). [Letter to A.J. Ditman]. National Archives and Record Administration II (Records of the American National Red Cross, Collection \#ANRC, Central Files, 1881-1982 (1935-1946 Segment), 224 Sports Benefits Basketball). College Park, MD.

Isaacs, N.D. (1975). All the Moves: A History of College Basketball. New York, NY: J.B. Lippincott.

Kerkhoff, B. (1996). Phog Allen: The Father of Basketball Coaching. Indianapolis, IN: Masters Press.

Kieran, J. (1942, January 27). Sports of the Times: At Red Cross Purposes. The New York Times. Retrieved at http://www.proquest.umi.com

Kieran, J. (1942, February 22). Sports of the Times: A Bouncing Game. The New York Times. Retrieved at http://www.proquest.umi.com 
Kieran, J. (1942, March 28). Sports of the Times: Glancing in All Directions. The New York Times. Retrieved at http://www.proquest.umi.com

L.I.U. Five to Play C.C.N.Y. Saturday. (1942, March 24). The New York Times. Retrieved at http://www.proquest.umi.com

Litsky, F. (2005, August 18). N.C.A.A. Buys N.I.T. for \$56.5 Million. The New York Times. Retrieved at http://www.nytimes.com

Madison Square Garden. (1943, February 19). College Basketball at Madison Square Garden [Press Release]. New York, NY. Records of the American National Red Cross (Collection \#ANRC, Central Files, 1881-1982 (1935-1946 Segment), 224 Sports Benefits Basketball). College Park, MD.

Morris, E.B. (1938, December 13). Basketball Rebounds: N.C.A.A. College Title Tournament Leaves Major Court Centers Out in Cold. [Clipping from The New York Tribune]. Copied from Ohio State University Archives. Copy in possession of author.

Morris, E.B. (1938, December 14). Basketball Rebounds: Tourney Set for Kansas City in March Is Not N.C.A.A. Title Event. [Clipping from The New York Tribune]. Copied from Ohio State University Archives. Copy in possession of author.

Morris, E.B. (1939, January 25). Met. Basketball Writers Vote Dates for 2d College Tourney. [Clipping from The New York Tribune]. Copied from Ohio State University Archives. Copy in possession of author.

National Association of Basketball Coaches. (1938). National Association of Basketball Coaches Annual Convention Proceedings, 1938. Chicago, Illinois. NABC folder. NCAA archives, Indianapolis, IN.

National Association of Basketball Coaches. (1967). National Association of Basketball Coaches Guide and Procedures [Book]. La Jolla, CA: Clifford Wells. Walter S. Byers Papers. NCAA archive, Indianapolis, IN.

National Collegiate Athletic Association. (1939). 1939 NCAA Yearbook [Book]. City, ST. 1930- 39 Folder. NCAA archive, Indianapolis, IN.

National Collegiate Athletic Association. (1940). 1940 NCAA Yearbook [Book]. City, ST. 1940- 49 Folder. NCAA archive, Indianapolis, IN.

National Collegiate Athletic Association. (1942). 1942 NCAA Yearbook [Book]. City, ST. 1940- 49 Folder. NCAA archive, Indianapolis, IN.

National Collegiate Athletic Association. (1943). 1943 NCAA Yearbook [Book]. City, ST. 1940- 49 Folder. NCAA archive, Indianapolis, IN.

National Collegiate Athletic Association. (1944). 1944 NCAA Yearbook [Book]. City, ST. 1940- 49 Folder. NCAA archive, Indianapolis, IN.

National Collegiate Athletic Association. (1945). 1945 NCAA Yearbook [Book]. City, ST. 1940- 49 Folder. NCAA archive, Indianapolis, IN.

National Collegiate Athletic Association. (1946). 1946 NCAA Yearbook [Book]. City, ST. 1940- 49 Folder. NCAA archive, Indianapolis, IN.

National Collegiate Athletic Association. (1951). 1951 NCAA Yearbook [Book]. City, ST. 1950- 59 Folder. NCAA archive, Indianapolis, IN.

NCAA Basketball Tournament Committee. (1954, July 9-10). Minutes of the NCAA University Basketball Tournament Committee. NABC Folder. NCAA archive, Indianapolis, IN.

NCAA National Collegiate Basketball Tournament Handbook. (1956). Tournament Structure. Basketball holdings. NCAA archive, Indianapolis, IN.

NCAA University Basketball Tournament Committee. (1955, July 6-7). Minutes of the NCAA University Basketball Tournament Committee. NABC Folder. NCAA archive, Indianapolis, IN.

NCAA University Basketball Tournament Committee. (1956, June 25-26). Minutes of the NCAA University Basketball Tournament Committee. NABC Folder. NCAA archive, Indianapolis, IN. 
NCAA University Basketball Tournament Committee. (1957, July 1-3). Minutes of the NCAA University Basketball Tournament Committee. NABC Folder. NCAA archive, Indianapolis, IN.

NCAA University Basketball Tournament Committee. (1960, July 13-15). Minutes of the NCAA University Basketball Tournament Committee. NABC Folder. NCAA archive, Indianapolis, IN.

NCAA University Basketball Tournament Committee. (1961, July 9-11). Minutes of the NCAA University Basketball Tournament Committee. NABC Folder. NCAA archive, Indianapolis, IN.

NCAA University Basketball Tournament Committee. (1962, July 6-8). Minutes of the NCAA University Basketball Tournament Committee. NABC Folder. NCAA archive, Indianapolis, IN.

NCAA University Basketball Tournament Committee. (1968, July 8-11). Minutes of the NCAA University Basketball Tournament Committee. NABC Folder. NCAA archive, Indianapolis, IN.

Ned Irish Asks Allen to Prove Betting Charge. (1944, October 21). The Chicago Tribune. Retrieved at http://www.proquest.umi.com

O’Riley, F.J. (1939, January 25). College Invitation Tournament to be Held in March by Basketball Writers. The New York Times. Retrieved at http://www.proquest.umi.com

Olsen, H.G. (1938). Report of the Basketball Tournament Committee. In National Collegiate Athletic Association (Ed.), 1938NCAA Yearbook (p. 42). Middletown, CT: Press of Pelton and King.

Olsen, H.G. (1940). General Plans for the Tournament. In O. Tower (Ed.), Spalding's Official Basket Ball Guide, 1939-40 (pp. 9). New York, NY: American Sports.

Olsen, H.G. (1941). Second National Collegiate A.A. Basketball Tournament. In O. Tower (Ed.), Spalding's Official Basket Ball Guide, 1940-41 (pp. 15). New York, NY: American Sports.

Olsen, H.G., \& St. Clair, J.W. (1944). Report of Rules and Tournament Committees: Basketball. In National Collegiate Athletic Association (Ed.), NCAA Yearbook, 1944 (p. 55). Copy retrieved in 1940-49 Folder, NCAA archive, Indianapolis, IN.

Olsen, H.G., \& St. Clair, J.W. (1945). Report of Rules and Tournament Committees: Basketball. In National Collegiate Athletic Association (Ed.), NCAA Yearbook, 1945 (p. 54). Copy retrieved in 1940-49 Folder, NCAA archive, Indianapolis, IN.

Olsen, H.G., \& St. Clair, J.W. (1946). Report of Rules and Tournament Committees: Basketball. In National Collegiate Athletic Association (Ed.), NCAA Yearbook, 1946 (pp. 38-49). Copy retrieved in 1940-49 Folder, NCAA archive, Indianapolis, IN.

Red, C.G.L. College Tourney Winners to Meet at Garden April 1. (1943, February 19). The New York Times. Retrieved at http://www.proquest.umi.com

Red Cross Names Sports Committees. (1945, January 19). The New York Times. Retrieved at http://www.proquest.umi.com

Red Cross Reports on Aid from Sports. (1946, January 12). The New York Times. Retrieved at http://www.proquest.umi.com

Report of Tournament and Olympic Committee. (1939). National Association of Basketball Coaches Annual Convention Proceedings, 1939. NABC folder, NCAA archives, Indianapolis, IN.

Richardson, W.D. (1944, March 30). St. John's Favored to Beat Utah in Red Cross Basketball Tonight. The New York Times. Retrieved at http://www.proquest.umi.com

Richardson, W.D. (1945, March 29). Giant Centers Top Court Bill Tonight. The New York Times. Retrieved at http://www.proquest.umi.com

Rosen, C. (1978). Scandals of '51: How the Gamblers Almost Killed College Basketball. New York: Rinehart, and Winston. 
Sheehan, J. (1938, March 18). Honors Garnered by Temple's Five: Gains Championship Award and Shields is Voted the Outstanding Player. The New York Times. Retrieved at http://www.proquest.umi.com

Simon, M. (1942, March 21). Letters to the Sports Editor: Why Not C.C.N.Y.-L.I.U.? The New York Times. Retrieved at http://www.proquest.umi.com

Smith, R.A. (2001). Play-by-Play: Radio, Television, and Big-Time College Sport. Baltimore, MD: The Johns Hopkins University Press.

Sports will help in Red Cross Drive. (1944, February 16). The New York Times. Retrieved at http://www.proquest.umi.com

Stooksbury, D. (2010). National Title: The Unlikely Tale of the NAIB Tournament. Bradenton Beach, FL: Higher Level.

Strauss, E. (1944, March 19). Full Program Set for Tourney Fives: Utah-Kentucky, CanisiusOklahoma Aggies in Garden Twin Bill Tomorrow. The New York Times. Retrieved at http://www.proquest.umi.com

Strauss, M. (1946, March 26). Oklahoma Aggies in Garden Tonight. The New York Times. Retrieved at http://www.proquest.umi.com

Tennessee Becomes Third Quintet to Enter National Invitation Tournament at Garden. (1945, March 4). The New York Times. Retrieved at http://www.proquest.umi.com

The Rumble. An Off-the-Ball Look at Your Favorite Sports Celebrities. (2006, December 31). The New York Post. Retrieved at http://www.nypost.com 